\title{
Perbandingan Efek Getah Tanaman Jarak Pagar (Jatropha Curcas L) dengan Lendir Bekicot (Achantina Fulica) terhadap Lama Penyembuhan Luka pada Mencit Jantan Galur Swiss Webster
}

\author{
Wiwit Kesumaningrum* ${ }^{*}$ R. Anita Indriyanti \\ Prodi Akuntansi, Fakultas Ekonomi dan Bisnis, Universitas Islam Bandung, \\ Indonesia.
}

*wiwitkesumaningrum733@gmail.com,r.anitaindriyanti@gmail.com

\begin{abstract}
A wound is a break in body tissue from the epithelial layer of the skin to the inner layer, such as subcutaneous tissue, fat, muscle, and bone. Jatropha sap and snail slime are natural ingredients that can be used in the treatment of wounds. Jatropha sap contains tannins, alkaloids, and flavonoids which function as antiinflammatory, while snail mucus contains achantin isolate which has anti-bacterial and anti-inflammatory effects. The purpose of this study was to compare the effect of jatropha (Jatropha Curcas L) and snail slime (Achantina fulica) on the duration of wound healing in Swiss Webster male mice. This study was a laboratory experimental study with a completely randomized design method on 24 male white mice strains. Swiss Webster. An incision was made on each mouse $1.5 \mathrm{~cm}$ long and $2 \mathrm{~mm}$ deep. The experimental animals were divided into 4 groups, namely the negative control group which was not given any treatment, the positive control group was given $10 \%$ povidone iodine, group I was given jatropha plant sap at a dose of 2 times per day with 2 drops of Pasteur pipette and group II snail mucus 2 times per day with 2 drops of Pasteur pipette. The wound observer was carried out for 14 consecutive days starting one day after the treatment. All mice in the positive control and negative control experienced healing (100\%) and only a part of the mice $(50 \%)$ in the group given karak plant sap and snail mucus who experienced healing. In the treatment of jatropha sap has no effect on wound healing time, as well as snail mucus there is no effect in the duration of healing wounds, but wounds heal faster using castor plant sap.
\end{abstract}

Keywords: Jatropha Sap, Snail Mucus, Wound, Wound Healing.

\begin{abstract}
Abstrak. Getah tanaman jarak pagar dan lendir bekicot merupakan salah satu bahan alam yang dapat digunakan dalam pengobatan luka. Getah tanaman jarak pagar mengandung tanin,alkaloid, serta flavonoid yang berfungsi sebagai antiinflamasi, sedangkan lendir bekicot mengandung isolat achantin yang memiliki efek anti bakteri dan anti inflamasi, sehingga membantu untuk mempercepat penyembuhan luka. Tujuan penelitian ini untuk membandingkan efek getah tanaman jarak pagar (Jatropha Curcas L) dengan lendir bekicot (Achantina fulica) terhadap lama penyembuhan luka pada mencit jantan galur Swiss Webster. Penelitian ini merupakan penelitian eksperimental laboratoris dengan pendekatan acak lengkap terhadap 24 ekor mencit putih jantan galur Swiss Webster. Luka secara insisi dibuat pada masing-masing mencit sepanjang $1.5 \mathrm{~cm}$ dengan kedalaman $2 \mathrm{~mm}$. Hewan coba dibagi menjadi 4 kelompok yaitu kelompok kontrol negatif yang tidak diberikan perlakuan apapun, kelompok kontrol positif yang diberikan povidon iodin $10 \%$, kelompok I diberi getah tanaman jarak dengan dosis $2 \mathrm{x} /$ hari sebanyak 2 tetes dan kelompok II lendir bekicot $2 \mathrm{x} /$ hari sebanyak 2 tetes. Pengamatam ukuran luka dilakukan selama 14 hari berturut-turut yang dimulai satu hari setelah pemberian perlakuan. Luka diamati selama 14 hari berturu-turut. Seluruh mencit pada kontrol positif dan kontrol negatif mengalami penyembuhan luka (100\%) dan hanya sebagian mencit $(50 \%)$ pada kelompok yang diberikan getah tanaman karak dan lendir bekicot yang mengalami penyembuhan. Pada perlakuan getah tanaman jarak tidak memiliki efek terhadap lama penyembuhan luka, begitu juga dengan lendir bekicotpun tidak terdapat efek dalam lama penyebuhan luka, namun luka lebih cepat mengalami penyembuhan dengan menggunakan getah tanaman jarak. Hasil menunjukkan bahwa tidak terdapat perbedaan bermakna antara pemberian getah tanaman jarak terhadap penyembuhan luka $(\mathrm{p}=0,125)$. Karena nilai sig nya $>0,05$ artinya tidak terdapat perbedaan antara Kontrol negative, Kontrol positif, Kelompok 1 (Getah tanaman jarak), dan Kelompok 2 (Lendir bekicot). Pemberian getah tanaman jarak pagar dan lendir bekicot tidak memiliki efek terhadap lama penyembuhan luka pada mencit jantan galur Swiss Webster tetapi pemberian getah tanaman jarak pagar lebih baik dari pada lendir bekicot.
\end{abstract}

Kata Kunci: Getah Tanaman Jarak (Jatropha Curcas L), Lendir Bekicot (Achantina Fulica), Penyembuhan Luka. 


\section{A. Pendahuluan}

Kulit merupakan organ tubuh terluas serta terbesar yang berfungsi sebagai perlindungan dari gangguan mekanik dan kimiawi serta sebagai rasa sensasi sensor dan termoregulator. Kulit terdiri dari lapisan epidermis dan dermis. Epidermis merupakan lapisan terluar yang terdiri dari epithelium berlapis pipih sedangkan lapisan dermis terdiri dari jaringan ikat retikular. Kulit dapat mengalami kerusakan secara mekanik maupun kimiawi. Menyebabkan luka.

Luka adalah terputusnya jaringan tubuh mulai dari lapisan epitel kulit sampai ke lapisan dalam seperti jaringan subkutan, lemak, otot serta tulang. Penyembuhan luka adalah proses yang kompleks. Proses ini bertujuan untuk memperbaiki struktur kulit atau organ yang mengalami kerusakan setelah cedera. Proses normal penyembuhan luka akan segera terjadi saat kulit mengalami kerusakan akibat cedera. Terdapat 3 fase proses penyembuhan luka yaitu, fase inflamasi,nfase proliferasindan fase remodelling. Fase inflamasindimulai segera setelah terjadinya cedera, biasanya berlangsung 1 sampai 2 hari dan bertahan sampai 2 minggu. Setelah fase inflamasi dilanjutkan dengan mekanisme hemostatik untuk segera menghentikan darah dari tempat luka. Fase selanjutnya adalahnfasenproliferasinyang berlangsung antara 2nharinsampain3 minggu, dengan hasil akhir berupa pembentukan kolagen tipe 3. Fase ini terdiri dari 3 langkah.yaitu: granulasi, kontraksindannepitelialisasi. Tahap akhir penyembuhan luka adalah fase remodeling, yang berlangsung selama 3 minggu sampai 2ntahun. Proses perubahan kolagen terjadi pada fase ini yaitu perubahan dari kolagen tipe 3 menjadi kolagen tipe 1.

Luka yang tidak ditangani dengan adekuat dapat menyebabkan komplikasi berupa jaringan parut hipertrofik, keloid dan infeksi yang dapat menghambat proses penyembuhan luka. Penatalaksanaan luka yang umum digunakan adalah pemberian iodium povidon $0,5 \%$ yang bersifat bakteriostatik. Penggunaan iodiump ovidon yang berlebihanndapatnmenimbulkan beberapa efek samping berupa dermatitis, bengkak, gatal serta rangsangan nyeri pada daerah sekitarnluka. Adanya efek samping penggunaan iodium povidon dapat mempengaruhi kepatuhan pasien, sehingga perlu dipertimbangkan adanya alternatif terapi. Salah satu alternatif terapi yang dapat dikembangkan adalah penggunaan obat tradisional, diantaranya getah tanaman jarak pagar dan lendir bekicot.

Tanaman jarak pagar dipercaya dapat mempercepat penyembuhan luka karena pada getah tanaman jarak pagar mengandung tanin,alkaloid, serta flavonoid. Penelitian sebelumnya yang dilakukan oleh Napanggala.A, Susianti, dan Appriliana E menunjukkan adanya efek pada pemberian getah tanaman jarak terhadap penyembuhan luka. Hal ini dikarenakan getah tanaman jarak mengandung flavonoid yang berfungsi sebagai antiinflamasi.

Penelitiannsebelumnya,nyang dilakukannoleh Perez Wahyu Purnasari , menunjukkan bahwanlendirmbekicotnmampu 2 kali lebih cepat menyembuhkan luka dibandingkan dengan iodium povidon $10 \%$. Lendir bekicot mengandung isolat achantin yang efektif sebagai anti bakteri dan anti inflamasi, dan mampu membunuh bakteri yang terdapat di sekitar luka.

Efek tanaman jarak pagar dan ledir bekicot terhadap penyembuhan luka telah dibuktikan melalui penelitian-penelitian sebelumnya, namun penelitian yang membandingkan efek getah tanaman jarak pagar dan lender bekicot terhadap lama waktu penyembuhan luka hingga saat ini belum pernah dilakukan. Tujuan penelitian adalah untuk membandingkan efektifitas getah tanaman jarak pagar dan lendir bekicot terhadap lama penyembuhan luka pada mencit jantan galur Swiss Webster.

\section{B. Landasan Teori \\ Rancangan Penelitian}

Penelitian ini merupakan penelitian eksperimental pada mencit putih (Mus musculus) jantan galur Swiss Webster menggunakan metode eksperimental laboratoris dengan rancangan post test control only group desain. Populasi penelitian ini adalah mencit jantan (Mus musculus) galur Swiss Webster berumur 2-3 minggu dengan berat 25-30 gram dan dalam keadaan sehat (aktif dan tidak cacat). Berdasarkan perhitungan dengan menggunakan rumus Federer, didapatkan jumlah minimal hewan coba yang akan digunakan pada masing-masing kelompok sebanyak 6 ekor mencit putih jantan untuk 4 kelompok perlakuan, sehingga jumlah total mencit yang dibutuhkan adalah 24 ekor. Setiap kelompok perlakuan ditambahkan 10\%, untuk 
mengantisipasi kematian mencit, sehingga jumlah keseluruhan hewan coba yang akan digunakan pada empat kelompok perlakuan adalah 28 ekor.

Prosedur penelitian ini sudah sesuai dengan etik No.0103/KEPK-Unisba/X/2020, hewan coba akan di tempatkan dalam kandang berukuran 24 x 31 x $16 \mathrm{~cm}$ Seluruh mencit diadaptasi terlebih dahulu selama 7 hari dengan memberikan pakan standar mencit yaitu pellet 551 (diproduksi oleh PT. Charoen Pokphand) dan diberi minum serta. Setelah dilakukan adaptasi seluruh kelompok dibuat luka sayat dipunggung mencit, dengan cara mencit disuntikkan lidokain yang merupakan obat golongan anastesi melalui subkutan dengan dosis $0.2 \mathrm{ml}$ per ekor yang dilakukan oleh tenaga ahli profesional, mencit dicukur rambutnya di daerah punggung bagian atas menggunakan pencukur rambut, daerah punggung bagian atas disekitar area yang telah dicukur kemudian dibersihkan dengan alkohol $70 \%$ dibuat luka insisi sepanjang $1,5 \mathrm{~cm}$ dengan kedalaman $2 \mathrm{~mm}$ mencapai subkutan menggunakan pisau bedah, Tahap selanjutnya adalah perlakuan sesuai dengan pembagian kelompoknya, kontrol negatif yaitu tidak diberikan perlakuan apapun, selanjutnya kontrol positif dengan diberikan perlakuan berupa pemberian povidon iodin $10 \%$ secara topikal 2 kali perhari dengan 2 pipet pasteur, lalu kelompok I, diaplikasikan getah tanaman jarak secara topikal, $2 \mathrm{x} /$ hari dengan 2 tetes $(2 \mathrm{x} 0,5 \mathrm{cc})$ per ekor, dan kelompok II diaplikasikan lendir bekicot secara topikal $2 \mathrm{x} / \mathrm{hari}$ dengan dosis $100 \%$ lendir bekicot, selanjutnya dengan menggunakan $3(0,5 \mathrm{cc})$ tetes pipet Pasteur lalu diberikan 2 kali perhari. Pengamatan dilakukan selama 14 hari dengan mengevaluasi lama penyembuhan luka mencit. Data yang didapat diolah dengan uji normalitas Shapiro-Wilk dan homogenitas Levene.

\section{Prosedur Pengumpulan dan Analisi Data}

Sampel yang terpilih akan dibagi menjadi 4 kelompok yaitu kelompok kontrol negatif, kontrol positif, kelompok I yang diberi getah tanaman jarak pagar dosis 2 tetes pipet Pasteur $(2 \times 0,5 \mathrm{cc})$ sebanyak 2 kali per hari, dan kelompok II yang diberikan lendir bekicot dosis dosis $100 \% 3$ tetes ( $3 \times 0,5 \mathrm{cc})$ sebanyak 2 kali perhari, penyembuhan luka ditandai dengan menutupnya luka (ukuran $0 \mathrm{~cm}$ ) dan lama penyembuhan luka dinilai berdasarkan waktu yang dibutuhkan hingga luka menutup setelah diberikan perlakuan. Penelitian ini telah mendapatkan persetujuan dari Komisi Etik Penelitian Kesehatan (KEPK) dari Fakultas Kedokteran Universitas Islam Bandung melalui surat No.0103/KEPK-Unisba/X/2020.

\section{Pembahasan dan Diskusi}

\section{Hasil Penelitian}

Tabel 1 memperlihatkan perubahan panjang luka mencit selama 14 hari sejak diberikan perlakuan.

Tabel 1. Perubahan Panjang Luka

\begin{tabular}{|c|c|c|c|c|c|c|c|c|c|c|c|c|c|c|c|c|}
\hline \multirow{2}{*}{ Kelompok } & \multirow{2}{*}{ Mencit } & \multicolumn{15}{|c|}{ Perubahan Panjang Luka (cm) } \\
\hline & & o & $\mathbf{1}$ & 2 & 3 & 4 & 5 & 6 & 7 & 8 & 9 & 10 & 11 & 12 & 13 & 14 \\
\hline \multirow{6}{*}{$\begin{array}{c}\text { Kontrol } \\
\text { negatif }\end{array}$} & 1 & 1.5 & 1.5 & 1.5 & 1.3 & 1.1 & o & o & o & $\mathrm{O}$ & $\mathrm{O}$ & $\mathrm{O}$ & o & o & o & $\mathrm{O}$ \\
\hline & 2 & 1.5 & 1.4 & 1.4 & 1.3 & 1.3 & 1 & 0.5 & 0.4 & 0.4 & 0.3 & 0.2 & o & $\mathrm{O}$ & O & o \\
\hline & 3 & 1.5 & 1.5 & 1.4 & 1.3 & 1.3 & $\mathrm{O}$ & o & o & $\mathrm{O}$ & $\mathrm{O}$ & o & $\mathrm{O}$ & $\mathrm{O}$ & $\mathrm{O}$ & o \\
\hline & 4 & 1.5 & 1.5 & 1.4 & 1.4 & 1 & 0.7 & 0.7 & 0.7 & 0.5 & 0.5 & 0.5 & 0.3 & $\mathrm{O}$ & O & $\mathrm{O}$ \\
\hline & 5 & 1.5 & 1.5 & 1.5 & 1.4 & 0.7 & 0.3 & 0.3 & 0.3 & 0.3 & & O & o & O & O & o \\
\hline & 6 & 1.5 & 1.5 & 1.3 & 1.3 & 0.3 & O & o & o & O & o & o & & o & O & o \\
\hline \multirow{6}{*}{$\begin{array}{c}\text { Kontrol } \\
\text { positif }\end{array}$} & 1 & 1.5 & 1.4 & 1.4 & 1.4 & 1.3 & 1.1 & 1 & 0.7 & 0.7 & 0.6 & 0.6 & 0.5 & 0.5 & 0.3 & $\mathrm{O}$ \\
\hline & 2 & 1.5 & 1.5 & 1.5 & 1.5 & 1.5 & 0.9 & 0.7 & 0.5 & 0.5 & 0.4 & 0.4 & 0.3 & 0.3 & 0.2 & O \\
\hline & 3 & 1.5 & 1.5 & 1.5 & 1.5 & 1.4 & 1 & 0.5 & 0.2 & $\mathrm{O}$ & o & o & o & O & O & O \\
\hline & 4 & 1.5 & 1.5 & 1.5 & 1.4 & 1.4 & 1.3 & 0.8 & 0.5 & 0.5 & 0.4 & 0.4 & 0.4 & 0.4 & O & O \\
\hline & 5 & 1.5 & 1.4 & 1.4 & 1.4 & 1.4 & 1.1 & O & O & $\mathrm{O}$ & 0 & O & o & o & O & O \\
\hline & 6 & 1.5 & 1.5 & 1.5 & 1.5 & 1.4 & 1.2 & O & o & O & & O & O & O & 0 & O \\
\hline
\end{tabular}




\begin{tabular}{|c|c|c|c|c|c|c|c|c|c|c|c|c|c|c|c|c|}
\hline \multirow{6}{*}{$\begin{array}{c}\text { Kelompok } \\
1 \text { (getah } \\
\text { tanaman } \\
\text { jarak) }\end{array}$} & 1 & 1.5 & 1.4 & 1.4 & 1.2 & 1.2 & 1.2 & 1 & 1 & 1 & 1 & 0.7 & 0.7 & 0.7 & 0.5 & 0.5 \\
\hline & 2 & 1.5 & 1.5 & 1.5 & 1.4 & 1.3 & 1 & 0.7 & 0.4 & 0.4 & 0.3 & 0 & 0 & 0 & o & 0 \\
\hline & 3 & 1.5 & 1.4 & 1.4 & 1.4 & 1.3 & 1.3 & 1.2 & 1 & 0.7 & 0.7 & 0.6 & 0.5 & 0.5 & 0.4 & 0.3 \\
\hline & 4 & 1.5 & 1.4 & 1.4 & 1.4 & 1.4 & o & o & o & o & 0 & o & o & o & o & o \\
\hline & 5 & 1.5 & 1.5 & 1.4 & 1.4 & 1.3 & 1.3 & 1.2 & 1 & 1 & 0.7 & 0.5 & 0.5 & 0.5 & 0.4 & 0.3 \\
\hline & 6 & 1.5 & 1.4 & 1.4 & 1.4 & 1.4 & 0.4 & o & o & o & o & o & o & o & o & o \\
\hline \multirow{6}{*}{$\begin{array}{c}\text { Kelompok } \\
2 \text { (Lendir } \\
\text { bekicot) }\end{array}$} & 1 & 1.5 & 1.5 & 1.5 & 1.5 & 1.4 & 1 & o & o & o & o & 0 & o & o & o & o \\
\hline & 2 & 1.5 & 1.5 & 1.5 & 1.4 & 1.4 & 1.2 & 1 & 1 & 0.7 & 0.7 & 0.5 & 0.5 & 0.5 & 0.4 & 0 \\
\hline & 3 & 1.5 & 1.5 & 1.4 & 1.4 & 1.3 & 0.8 & 0.5 & 0.5 & 0.5 & 0.3 & 0.3 & 0.3 & 0.3 & 0.3 & 0.3 \\
\hline & 4 & 1.5 & 1.4 & 1.4 & 1.4 & 1.4 & 0.9 & 0.7 & 0.5 & 0.5 & 0.5 & 0.5 & 0.4 & 0.4 & 0.4 & 0.3 \\
\hline & 5 & 1.5 & 1.4 & 1.5 & 1.4 & 1.4 & 1.2 & 0.9 & 0.5 & 0.2 & o & o & o & o & o & o \\
\hline & 6 & 1.5 & 1.5 & 1.5 & 1.5 & 1.5 & 1 & 0.7 & 0.7 & 0.6 & 0.6 & 0.6 & 0.5 & 0.4 & 0.3 & 0.3 \\
\hline
\end{tabular}

Berdasarkan data pada tabel 1 terlihat bahwa seluruh mencit pada kelompok kontrol negatif dan positif mengalami penyembuhan luka, dengan lama penyembuhan luka yang berbeda-beda. Terdapat 3 ekor mencit dari kelompok yang diberi getah tanaman jarak dan 3 ekor mencit dari kelompok yang diberi lendir bekicot yang mengalami penyembuhan luka dengan lama waktu penyembuhan yang berbeda-beda.

Tabel 2. Rerata Perubahan Panjan Luka

\begin{tabular}{|c|c|c|c|c|c|c|c|c|c|c|c|c|c|c|c|c|}
\hline \multirow{2}{*}{ Kelompok } & & \multicolumn{15}{|c|}{ Panjang sisa luka (cm) } \\
\hline & & $\mathbf{o}$ & $\mathbf{1}$ & 2 & 3 & 4 & 5 & 6 & 7 & 8 & 9 & 10 & 11 & 12 & 13 & 14 \\
\hline Kontrol negatif & Mean & 1.5 & 1.5 & 1.4 & 1.3 & 1.0 & 0.7 & 0.5 & 0.5 & 0.4 & 0.4 & 0.4 & 0.3 & 0.0 & 0.0 & o.o \\
\hline Kontrol positif & Mean & 1.5 & 1.5 & 1.5 & 1.5 & 1.4 & 1.1 & 0.8 & 0.5 & 0.6 & 0.5 & 0.5 & 0.4 & 0.4 & 0.3 & 0.0 \\
\hline Kelompok 1 (getah tanaman jarak) & Mean & 1.5 & 1.4 & 1.4 & 1.4 & 1.3 & 1.0 & 1.0 & 0.9 & 0.8 & 0.7 & 0.6 & 0.6 & 0.6 & 0.4 & 0.4 \\
\hline Kelompok 2 (Lendir bekicot) & Mean & 1.5 & 1.5 & 1.5 & 1.4 & 1.4 & 1.0 & 0.8 & 0.6 & 0.5 & 0.5 & 0.5 & 0.4 & 0.4 & 0.4 & 0.3 \\
\hline
\end{tabular}

Berdasarkan rerata panjang luka di tabel 2 terlihat bahwa pada kelompok kontrol negatif penyembuhan luka (panjang luka $0 \mathrm{~cm}$ ) terjadi pada hari ke-12, sedangkan pada kelompok kontrol positif penyembuhan luka baru terjadi pada hari ke-14. Proses penyembuhan luka pada kelompok perlakuan belum terlihat hingga hari ke-14 pengamatan, baik yang diberikan getah tanaman jarak maupun lendir bekicot, meskipun pada hari ke-14 rerata panjang luka yang diberikan lendir bekicot lebih kecil $0,1 \mathrm{~cm}$ dibanding yang diberikan getah tanaman jarak. Namun jika dilihat berdasarkan tabel 1 dapat terlihat bahwa terdapat 3 ekor mencit pada kelompok yang diberikan getah tanaman jarak dan 2 ekor mencit pada kelompok yang diberikan lendir bekicot yang mengalami proses penyembuhan luka.

\section{Pembahasan}

Hasil penelitian ini menunjukkan bahwa kelompok kontrol negatif memperlihatkan efek penyembuhan luka yang lebih baik, jika dilihat berdasarkan waktu penyembuhan luka, dibanding kelompok positif maupun kelompok perlakuan. Penelitian yang dilakukan Ika Rahmawati menunjukkan adanya efek pada povidone iodine $10 \%$ dalam mempercepat penyembuhan luka, karena povidone iodin $10 \%$ memiliki manfaat yaitu sebagai antimikroba yang dapat membunuh bakteri. Namun pada kelompok perlakuan lama penyembuhan luka lebih lambat di bandingkan dengan kelompok kontrol, hal tersebut kemugkinan dikarenakan adanya kandungan yang tidak terdapat dalam getah tanaman jarak maupun lendir bekicot dikarenakan tidak dilakukannya uji fitokimia. Akan tetapi apabila dilihat berdasarkan proporsi luka sembuh, baik kontrol positif atau 
negatif memperlihatkan efek yang sama. Hasil ini kemungkinan disebabkan karena, kelompok perlakuan yang diberi getah tanaman jarak pagar memperlihatkan efek yang sama dengan kelompok yang diberikan lendir bekicot berdasarkan proporsi luka sembuh dan waktu penyembuhan luka. Kemungkinan hal ini dikarenakan getah tanaman jarak mengandung zat-zat yang bermanfaat diantaranya flavonoid yang dapat berfungsi sebagai antiinflamasi dan juga berfungsi dalam proses regenerasi atau perbaikan sel selanjutnya getah tanaman jarak mengandung saponin yang yang berfungsi dalam mempercepat pertumbuhan kolagen dalam proses penyembuhan luka hal ini selaras dengan penelitian sebelumnya yang di lakukan oleh Yeni Priyandari, dkk, menurut Harris, menyebutkan bahwa flavonoid juga bekerja dalam proses membunuh atau menghambat pertumbuhan mikroorganisme pada jaringan hidup. Dalam membunuh mikrorganisme bergantung pada beberapa faktor, misalnya konsentrasi serta lama paparan. Konsentrasi mempengaruhi penyerapan antiseptik, pada konsentrasi rendah, beberapa antiseptik menghambat fungsi biokimia membran bakteri, namun tidak akan membunuh bakteri tersebut, kemungkinan hal tersebut dapat menghambat dari proses penyembuhan luka pada perlakuan getah tanaman jarak.

Sedangkan pada lendir bekicot, mengandung achantia isolate dan kalsium. Achantia isolat bermanfaat sebagai antibakteri, sedangkan kalsium berperan dalam hemostasis. Lendir bekicot juga mengandung heparan sulfat yang bermanfaat dalam mempercepat penyembuhan luka dengan membantu proses pembekuan darah dan proliferasi sel fibroblas hal ini selaras pada penelitian sebelumnya yang dilakukan oleh S. Dwi Sulistyowati, dkk (2015). Berdasarkan hasil yang telah diperoleh dapat disimpulkan getah tanaman jarak memiliki efek lebih baik dari lendir bekicot. Saran untuk pnelitian ini yaiti, pengukuran panjang luka menggunakan penggaris biasa bisa digati dengan alat yang lebih akurat untuk pembacaan panjang luka mencit sehingga pembacaan antara orang yang satu dan lainnya bisa sama dan diperlukan penelitian lebih lanjut mengenai pengamatan waktu penyembuhan luka insisi pada jam yang sama setiap harinya selama penelitian sehingga bisa mendapatkan data akurat mengenai durasi efek yang dihaslkan dari bahan uji tersebut.

\section{Kesimpulan}

Pemberian getah tanaman jarak pagar (Jatropha curcas L) dan lendir bekicot (Achantina fulica) membutuhkan rerata waktu penyembuhan luka yang lebih lama dalam penelitian ini ( lebih dari 14 hari) dibanding povidon iodin.

\section{Konflik kepentingan}

Pada penelitian ini terdapat keterlambatan dalam mengambil data dikarenakan adanya pandemi yang mempersulit dalam pencarian lab hewan dikarenakan banyaknya lab hewan yang tutup dan juga pengurangan jumlah orang yang dapat melakukan penelitian dalam sebuah lab.

\section{Acknowledge}

Ucapan terima kasih penulis sampaikan kepada dekan Fakultas Kedokteran Universitas Islam Bandung dan Lab Hewan Fakultas Kedokteran Universitas Islam Bandung.

\section{Daftar Pustaka}

[1] Drake RL, Vogl AW, Mitchell AWM. Gray basic anatomi internasional. Amsterdam: Elsevier; 2012.

[2] Moore KL, Dalley AF, Agur AMR. Introduction to clinically oriented anatomy. Dalam: Taylor C, penyunting. Clinically oriented anatomy. Edisi ke-7. Philadelphia: Wolters Kluwer Lippincott Williams \& Wilkins; 2014.

[3] Primadina N, Basori A, Perdanakusuma DS. Proses penyembuhan luka ditinjau dari aspek mekanisme seluler dan molekuler. Qanun Med - Med J Fac Med Muhammadiyah Surabaya. 2019;3(1):31-43.

[4] Parakash BN, Solaki R. Role of medicinal plants in wound healing. Research Journal of Medicinal Plant. 2011;5:392-405.

[5] Napanggala A, Susanti AE, Apriliana E. Effect of jatropha's (jatropha curcas 1.) sap topically 
in the level of cuts recovery on white rats sprague dawley strain. Majority. 2014;3(5):2635.

[6] Sarimole E, Martosupono M, Semangun H. Manfaat jarak pagar (jatropha cucas). Program Studi Magister Biol Univ Kristen Satya Wacana. Prosiding Seminar Nasional Raja Ampat. 2014 Agustus 12-13;9-12.

[7] Napanggala A, Susanti AE, Apriliana E. Effect of jatropha's (jatropha curcas 1.) sap topically in the level of cuts recovery on white rats sprague dawley strain. Majority. 2014;3(5):2635.

[8] Sulisetyowati SD, Oktariani M. Perbandingan efektivitas lendir bekicot (achatina fulica) dengan kitosan. 2015 Oktober 7;2015:64-71.

[9] Mescher AL. Junqueira's basic histology text \& atlas. Edisi ke 14. Pennsylvania: McGrawHill Medical; 2015.

[10] Parakash BN, Solaki R. Role of medicinal plants in wound healing. Research Journal of Medicinal Plant. 2011;5:392-405.

[11] Pandey A, Mittal A. A review on wound healing. Journal of Pharmaceutical Research. 2017 Juli 7;1(4):2-4.

[12] Townsend CM, Beauchamp RD, Evers BM, Mattox KL. Sabiston textbook of surgery the biological basis of modern surgical practice.. Amsterdam: Elsevier; 2007.

[13] Santoso, BB. Deskripsi botani jarak pagar (jatropha curcas 1). Cetakan pertama. Lombok: Arga Puji Press; 2010.

[14] Kholilah M, Indriyanti RA, Budiman. Perbandingan antara efek lumatan daun petai cina (leucaena leucocephala) dan madu terhadap proses penyembuhan luka pada mencit. Prosiding Pendidikan Dokter. ISSN 2460-657X; (2):375-86.

[15] Sulisetyowati SD, Oktariani M. Perbandingan efektivitas lendir bekicot (achatina fulica) dengan kitosan. 2015 Oktober 7;2015:64-71.

[16] Purnasari PW, Fatmawati D, Yusuf I. Pengaruh lendir bekicot (achatina fulica) terhadap jumlah sel fibroblas pada penyembuhan luka sayat studi eksperimental pada kulit mencit (mus musculus). Sains Medika;. 2012;4(2):195-203. 